\title{
Expression of two alternative sigma factors of Synechococcus sp. strain PCC 7002 is modulated by carbon and nitrogen stress
}

\author{
Laurie F. Caslake, † Tanja M. Gruber and Donald A. Bryant \\ Author for correspondence: Donald A. Bryant. Tel: +1 814865 1992. Fax: +1 8148637024. \\ e-mail: dab14@psu.edu
}

Department of

Biochemistry and

Molecular Biology and

Center for Biomolecular

Structure and Function,

The Pennsylvania State

University, University Park,

PA 16802, USA

\begin{abstract}
The sigB and sigC genes, encoding two alternative sigma factors of the unicellular marine cyanobacterium Synechococcus sp. PCC 7002, were cloned and characterized. Strains in which the sigB and sigC genes were insertionally inactivated were viable under standard laboratory conditions, indicating that SigB and SigC are group 2 sigma factors. Starvation for either nitrogen or carbon caused an increase in sigB mRNA levels. Transcripts for the sigC gene initially increased but then decreased during nitrogen and carbon starvation. The SigC protein could not be identified in cyanobacterial extracts using antisera to Synechococcus Sp. PCC 7002 SigA or RpoD from Bacillus subtilis. The ratio of the principal vegetative sigma factor, SigA, to SigB decreased during either nitrogen starvation or carbon starvation, and the levels of SigB also increased in the sigC mutant strain. These results imply that SigB and SigC play roles in modifying transcription in response to changes in carbon and nitrogen availability in this cyanobacterium.
\end{abstract}

Keywords: RNA polymerase, sigma factors, transcription, cyanobacteria, nutrient stress

\section{INTRODUCTION}

The major control point for gene expression is transcription, and DNA-dependent RNA polymerase (EC 2.7.7.6), through its interactions with the promoter regions of genes and operons as well as its catalytic activities in RNA synthesis, is the key enzyme of transcription. In contrast to the apparent complexity of the transcription initiation process in eukaryotes (Goodrich \& Tjian, 1994) and archaea (Bult et al., 1996), eubacteria require a single polypeptide, known as the sigma factor, to confer promoter-specific transcription initiation capability on RNA polymerase (Burgess et al., 1969). Two major families of sigma factors are known to occur in eubacteria: the $\sigma^{70}$ family (Helmann \& Chamberlin, 1988) and the $\sigma^{54}$ (RpoN) family (Kustu et al., 1989).

During exponential-phase growth of eubacteria, the primary, or group 1 (Lonetto et al., 1992), sigma factor

\footnotetext{
†Present address: Department of Biology, State University of New York - College at Fredonia, Fredonia, NY 14063, USA.

The GenBank accession numbers for the nucleotide sequences reported in this paper are U82435 (sigB) and U82436 (sigC).
}

directs transcription. In the case of Escherichia coli, RpoD (or $\sigma^{70}$ ) recognizes promoters with the consensus DNA sequence motif $5^{\prime}$ TATAAT centred at about -10 with respect to the transcription start at +1 , and $5^{\prime}$ TTGACA centred at about -35 ; these two elements are typically separated by $17 \mathrm{bp}$ of nonconserved sequence (Harley \& Reynolds, 1987). Functional studies of RpoD $\left(\sigma^{43}\right.$ or $\left.\sigma^{\mathrm{A}}\right)$ of Bacillus subtilis (Moran, 1993; Haldenwang, 1995) suggest that the promoters of this Gram-positive eubacterium are similar in sequence and recognized in a manner similar to those of E. coli. The $\mathrm{X}$-ray structure of a significant portion of the $\sigma^{70}$ sigma factor of E. coli, including the region of the protein that interacts with the -10 motif of the promoter, has recently been solved at $2.6 \AA$ resolution (Malhotra et al., 1996). The structure suggests that the -10 promoter motif is recognized by an exposed, amphipathic $\alpha$-helix within region 2.4 of the $\sigma^{70}$ protein; an adjacent region of the same $\alpha$-helix, derived from region 2.3, contains four conserved aromatic residues that are probably involved in melting of the DNA duplex at the promoter. The structure of the carboxy-terminal portion of $\sigma^{70}$, that is known to interact with the -35 region of the promoter (Helmann \& Chamberlin, 1988; Siegele et al., 1989), is not known. 
Although eubacteria use a single polypeptide to confer promoter-specific transcription initiation capability on RNA polymerase, most eubacteria have the ability to synthesize several different sigma factors (Helmann \& Chamberlin, 1988; Lonetto et al., 1992). For example, E. coli can utilize seven sigma factors: RpoD $\left(\sigma^{70}\right)$, RpoH, RpoS, RpoE, FliA, FecI and RpoN (Mulvey \& Loewen, 1989; Kustu et al., 1989; Lonetto et al., 1992, 1994; Liu \& Matsumura, 1995). Sigma factors that are highly similar in sequence to group 1 sigma factors but which are not required for cell viability have been classified as group 2 sigma factors (Lonetto et al., 1992). A few organisms, including cyanobacteria, Streptomyces sp. and Chloroflexus aurantiacus, are unusual among eubacteria in having several group 2 sigma factors (Tanaka et al., 1991; Curtis \& Martin, 1994; Gruber \& Bryant, 1997). A much studied member of the group 2 subgroup is RpoS, which is responsible for specific transcription of genes during the post-exponential growth phase (McCann et al., 1991; Kolter et al., 1993). Finally, still more divergent members of the $\sigma^{70}$ protein family include the group 3 sigma factors such as $\mathrm{RpoH}$, which plays a key role in the heat-shock response of $E$. coli (Grossman et al., 1984; Bukau, 1993; Mager \& de Kruijff, 1995), sigma factors that play important roles in sporulation of B. subtilis (Stragier, 1991; Haldenwang, 1995), the extracellular factor (ECF) family (including RpoE and FecI; Lonetto et al., 1994), and sigma factors involved in flagellar synthesis (e.g., FliA; Liu \& Matsumura, 1995).

Although cyanobacteria may have as many as four group 2 sigma factors (Curtis \& Martin, 1994; Kaneko et al., 1996a, b; Gruber \& Bryant, 1997), the roles of these sigma factors in gene regulation and cellular physiology are just beginning to be investigated. Two genes encoding type 2 sigma factors, $\operatorname{sig} B$ and $\operatorname{sig} C$, have been isolated from Anabaena sp. PCC 7120 (Brahamsha \& Haselkorn, 1992). These genes were only transcribed in the period from $6 \mathrm{~h}$ to $24 \mathrm{~h}$ after removal of combined nitrogen from the growth medium. Strains with null mutations in $\operatorname{sig} B$ or $\operatorname{sig} C$ were viable under normal photoautotrophic conditions and were unaffected in their ability to perform nitrogen fixation and to differentiate heterocysts. In a more recent study, it has been suggested that the RpoD2 sigma factor, which appears to be the homologue of SigB of Anabaena sp. PCC 7120, modifies the circadian expression of a subset of genes in the cyanobacterium Synechococcus sp. PCC 7942 (Tsinoremas et al., 1996).

We are interested in the regulation of gene expression in the unicellular marine cyanobacterium Synechococcus sp. PCC 7002. The sigA gene, encoding the group 1 sigma factor of this organism, was previously cloned and its product characterized (Caslake \& Bryant, 1996). To further understanding of the role of group 2 sigma factors in gene expression in cyanobacteria, in the present study we have characterized two alternative sigma factors, denoted SigB and SigC, of Synechococcus sp. PCC 7002. Changes in the relative abundances of these sigma factors during carbon and nitrogen limi- tation provide insights into their possible biological functions.

\section{METHODS}

Bacterial strains, plasmids, and growth conditions. The unicellular marine cyanobacterium Synechococcus sp. PCC 7002 strain PR6000 (formerly Agmenellum quadruplicatum strain PR-6) was grown in medium A supplemented with sodium nitrate (designated medium $\mathrm{A}^{+}$) as described by Caslake \& Bryant (1996). For growth of kanamycin-resistant transformants, medium $\mathrm{A}^{+}$was supplemented with $200 \mathrm{mg}$ kanamycin $\mathrm{I}^{-1}$. Cells for nitrogen starvation experiments were grown as described by Caslake \& Bryant (1996). For carbon starvation experiments, cells were initially grown in replete medium to an average $\mathrm{OD}_{550}$ of 0.5 ; cultures were then bubbled with nitrogen gas for the specified time period.

E. coli HB101 was used as the host for cosmid pHC79, and E. coli DH5 $\alpha$ (Bethesda Research Laboratories) was used for all other recombinant DNA manipulations except protein overproduction. Plasmid pUC19 (Yanisch-Perron et al., 1985) was used for all routine cloning and sequencing procedures. E. coli strains were grown on Luria-Bertani (LB) medium, supplemented, when appropriate, with ampicillin $\left(100 \mathrm{mg}^{-1}\right.$ in LB), chloramphenicol (25 mg l-1 in LB) or kanamycin $\left(40 \mathrm{mg} \mathrm{l}^{-1}\right.$ in LB). E. coli BL21(DE3) was used for overproduction of the SigB protein, and BL21(DE3)pLysS was used for overproduction of the SigC protein (Studier et al., 1990).

DNA and RNA isolation, DNA sequence analysis, and Southern and Northern hybridization analyses. Procedures for the preparation of plasmid DNA from E. coli, the isolation of DNA and RNA from Synechococcus sp. PCC 7002 strain PR6000, DNA sequence analysis, Southern and Northern (RNA) blot hybridization, the isolation and radioisotopic labelling of DNA fragments, and primer extension mapping of 5 ' endpoints of mRNA, have been described elsewhere (Caslake \& Bryant, 1996). Oligonucleotides were synthesized on a model 380A Applied Biosystems automated DNA synthesizer at the Biotechnology Institute, Pennsylvania State University.

Cloning, insertional inactivation, and transformation procedures. The sigB gene (encoded on a $6.0 \mathrm{kbp} E c o \mathrm{RI}$ genomic DNA fragment; see Caslake \& Bryant, 1996) and the sigC gene (encoded on a $3.4 \mathrm{kbp}$ EcoRI fragment; see Caslake $\&$ Bryant, 1996) were isolated by screening a cosmid library of EcoRI partial digestion products of Synechococcus sp. PCC 7002 strain PR6000 total DNA cloned in cosmid vector pHC79. An 820 bp KpnI-BglII fragment containing the sigA gene was the hybridization probe. A $1.62 \mathrm{kbp}$ region encoding $\operatorname{sig} B$ and a $2 \cdot 25 \mathrm{kbp}$ region encoding $\operatorname{sig} C$ were sequenced (Fig. 1). Synechococcus sp. strain PR6501, in which the $\operatorname{sig} B$ gene is insertionally inactivated with a DNA fragment encoding kanamycin resistance, was constructed by transformation (Buzby et al., 1983) with a DNA construct (Fig. 1a) in which a $1.32 \mathrm{kbp} S m a I$ fragment encoding the aphIl gene of Tn5 was inserted into the unique $S m a I$ site of the sigB gene (aphII encodes aminoglycoside 3'-phosphotransferase II). Synechococcus sp. strain PR6502, in which the sigC gene is insertionally inactivated with the aphII gene, was constructed by transformation with a DNA construct (Fig. 1b) in which a $1.32 \mathrm{kbp}$ EcoRI fragment encoding the aphII gene of Tn5 was inserted into the unique $S t y \mathrm{I}$ site of the $s i g C$ gene.

Overproduction of SigB and SigC. The $s i g B$ gene was amplified by PCR using primers designed to create an NdeI site overlapping the start codon of the gene and a BglII site 
(a)

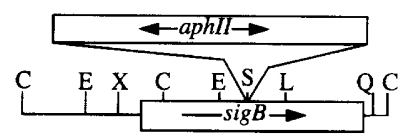

(b)

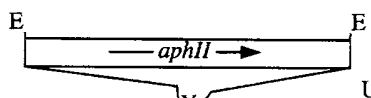

$\mathbf{R}$

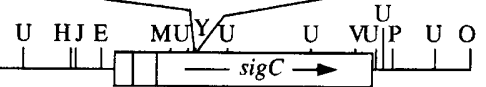

Fig. 1. Physical maps of (a) the $1.62 \mathrm{kbp}$ Hincll fragment containing the sigB gene and (b) the $2.25 \mathrm{kbp} E$ EcoRV-Bcll fragment containing the sig $C$ gene, encoding alternative sigma factors of the RNA polymerase of Synechococcus sp. PCC 7002. Arrows indicate the direction of transcription. The vertical lines in the box representing the $\operatorname{sig} C$ gene indicate the position of alternative translation initiation codons. The aph/l gene, which encodes aminoglycoside 3'-phosphotransferase II and confers resistance to kanamycin, was inserted into the Smal site of the sigB gene (in both orientations as indicated by the arrows) and the Styl site of the $\operatorname{sig} C$ gene in mutational studies. Restriction enzyme sites are: E, EcoRI; C, Hincll; X, Xbal; S, Smal; L, Sspl; R, EcoRV; U, Sau3Al; H, HindIII; J, Sstl; Y, Styl; O, Bcll; M, Xmnl; Q, Bsml; V, Aval.

downstream from the stop codon. The sigC gene was amplified by PCR using primers designed to create an NcoI site overlapping the start codon of the gene and a BglII site downstream from the stop codon. The PCR-amplified products were extracted with phenol, purified by gel electrophoresis, and digested with $B g l I I$ and either $N d e I$ or $N c o l$. The digestion products were ligated into pET11a digested with NdeI and BamHI (for sigB) or pET3d digested with NcoI and $B a m \mathrm{HI}$ (for sigC). The pET11a/SigB plasmid was transformed into E. coli BL21(DE3). The pET3dSigC plasmid was transformed into E. coli BL21(DE3)pLysS. E. coli BL21(DE3) cells harbouring the pET11a/SigB plasmid and BL21(DE3)pLysS cells harbouring the $\mathrm{pET} 3 \mathrm{~d} / \mathrm{SigC}$ plasmid were grown in NZCYM medium supplemented with the appropriate antibiotics at $30^{\circ} \mathrm{C}$ with shaking. When the $\mathrm{OD}_{600}$ of the cell culture reached 0.6 , IPTG was added to $0.5 \mathrm{mM}$. The cells were harvested $5 \mathrm{~h}$ after induction.

SDSPAGE, immunoblot analysis, and protein sequencing. RNA polymerase of Synechococcus sp. PCC 7002 was partially purified as previously described (Caslake \& Bryant, 1996). SDS-PAGE was performed as described by Laemmli (1970), and immunoblotting of proteins on nitrocellulose membranes (Schleicher \& Schuell) was performed as described by Caslake \& Bryant (1996). Rabbit antibodies against the Synechococcus sp. PCC 7002 SigA protein were produced as previously described (Caslake \& Bryant, 1996). Rabbit antibodies against the Bacillus subtilis $\mathrm{RpoD} / \sigma^{43}$ protein were kindly provided by Dr Roy Doi (University of California, Davis). Aminoterminal and carboxy-terminal protein sequencing was performed by Dr Jindong Zhao (Applied Biosystems).

\section{RESULTS}

\section{Cloning and sequence analysis of the sigB and sigC genes}

Previous Southern hybridization results had demonstrated the presence of at least five sigma factor homologues in Synechococcus sp. PCC 7002 (Caslake \&
Bryant, 1996). The $\operatorname{sig} B$ and $\operatorname{sig} C$ genes were isolated from an EcoRI partial-digestion cosmid library in vector $\mathrm{pHC79}$, and the nucleotide sequences of these genes were determined. These sequences have been deposited in GenBank under the accession numbers U82435 (sigB) and U82436 (sigC). A physical map of the $1.623 \mathrm{kbp}$ $H$ incll fragment encoding sigB is shown in Fig. 1(a). The sig $B$ gene predicts a polypeptide of 328 amino acids (38176 Da) (Fig. 2), and no additional genes or open reading frames were identified in the region sequenced through searches of the databases. The ATG start codon for the $\operatorname{sig} B$ gene is preceded by a weak ribosomebinding sequence $\left(5^{\prime}\right.$-AAAG- $\left.3^{\prime}\right)$ at a typical distance $(-9$ to -6$)$ from the start codon, but a much better ribosome-binding sequence ( $5^{\prime}$-AAGGAG-3') is observed further upstream at -17 to -12 relative to the start codon. An inverted repeat with the potential to form a GC-rich stem-loop followed by a run of T residues occurs immediately downstream from the $\operatorname{sig} B$ gene. This sequence resembles typical rho-independent transcription termination signals in E. coli (Richardson \& Greenblatt, 1996) and could play a role in transcription termination, mRNA stabilization, or both processes.

A physical map of the $2.257 \mathrm{kbp} E c o \mathrm{RV}-B c l$ fragment encoding $\operatorname{sig} C$ is shown in Fig. 1(b). Three in-frame methionine codons, which could serve as translational start sites for the sigC gene, are indicated by vertical lines within the box representing the sigC gene in Fig. 1(b). The longest potential SigC polypeptide would contain 365 amino acids (42245 Da), the mid-length polypeptide would contain 336 amino acids (39073 Da), and the shortest polypeptide would contain 305 amino acids (35528 Da) (see Fig. 2). Each of these start codons is preceded by potential ribosome-binding sequences. An inverted repeat with the potential to form a GC-rich stem-loop followed by a run of $\mathrm{T}$ residues occurs immediately downstream from the sigC gene. This sequence strongly resembles rho-independent transcription termination signals in E. coli and could play a role in transcription termination, mRNA stabilization, or both processes (Richardson \& Greenblatt, 1996). The 3' end of the moeB (or $c h l N$ ) gene, encoding a protein that plays a role in molybdenum insertion into the molybdopterin cofactor of molybdo-enzymes (Nohno et al., 1988), was found on the complement strand from nucleotides 2257 to 2079 . No open reading frames with significant similarity to sequences in the databases were identified in the more than 700 nucleotides that were sequenced upstream from the $\operatorname{sig} C$ gene.

An alignment of the deduced amino acid sequences of the SigA, SigB and SigC sigma factors of Synechococcus sp. strain PR6000 is shown in Fig. 2. The two group 2 or alternative sigma factors, SigB and SigC, were about $46-47 \%$ identical in sequence to the group 1 or essential vegetative sigma factor, SigA. However, in the region implicated in binding the -10 hexamer (region 2.3/2.4), these three proteins are approximately $80 \%$ identical. In region 4.2, which is implicated in binding the -35 promoter motif, the pairwise percentage identity values 
Synechococcus sp. strain PR6000 SigA Synechococcus sp. strain PR6000 SigB Synechocystis sp. strain PCC 6803 RpoD (D63999) Anabaena sp. strain $7120 \mathrm{SigB}$

Synechococcus sp. PCC strain 7942 RpoD2 Synechococcus sp. strain PR6000 SigC

Synechocystis sp. strain PCC 6803 RpoD (D90908)
MTQATNPVLDQTRNEGDIDYSALAEAQIKEGTDYVELTLPTKKSRKAKTSRRKETATKKKPYTE

MPKVNLQ-QAPNNGKSSA MVTVTVILLLFIKESFRMPTANLS-SPTSPPTFTA MPNSTSQVTKLK-SKNNEFSYTA MSTSSAQYSP MFDTTTTNSLDPVYAQDSHQATELESSNSMVEAEFSETELTNLRGVRSRNE MSDMSSLSTPNTSAVDQWQALDGLADGQAIANDDPPAIEVTLGDGQQGSFNKAVSE

region 1.2

region 2

DSIRIYLQEIGRIRLLRAEEEIELARKIADLLELERMREQLTEHESRVPTDKEWAEAAGMP-LKDFRRRLFHGRRAKDKMVQSNLRLVVSIAKKYMNRGLSFQDL DMVRTYLREIGRVPLLTHEEEIVYGKQVQRLMALQEKRQTLEESLDRERTREEWAEAAQLT-PKQLQRDLQIGERAKRKMIEANLRLVVAIARNIKKRNLEFLDL DMVRSYLHEIGRVPLLTHEQEIILGKQVQQMMALLEHKKALADRLGREPSDPEWAEAADLS-VTKLHRYLGQGERAKRKMIEANLRLVVAIAKKYQKRNMEFLDL DAVSIYLHKI IRVPLLSHEQEIFFAQQVQQMMVMFTAKEELAEKLQREPTLQEWADKMQLK-EDVLLQQLSQGQIAKQKMIQANLRLVVSIAKKYQKRNLEFLDL DLVRAYLQEIGRVRLLTAEEELCFGRQVQRLMMLLDAQTELRDRLGHEPSKEEWAAAVDLN-LEDLDREIEQGQRAKRKMIEANLRLVVSIAKKYQKRHMEFLDL DTVGAFFKEWARY PLLKPDEEIQLAHSVKFLNDAEERRIELQEQLGRSPTNEEWASVLGLETVRQLNSALYKGRVAKRKMIRSNLRLVVSIAKRYLNRGVPFLDL DTVGAFFKEMARYPLLSAAEEVELARQIRLLVSAEDVRQQLTQQLERTPSLQEWGQALEFPQVRQFEIWLYQLRAAKRRMIRSNLRLVVSIAKRYLNRGVPFLDL

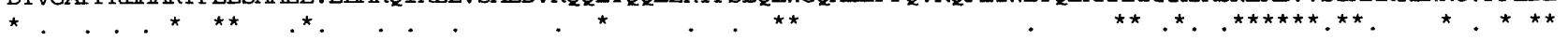

---- region $2.4 \quad---$

region 3

IQEGSLGLIRAAEKFDHEKGYKFSTYATWWIRQAITRAIADQSRTIRLPVHLYETISRIKKTTKILSQELGRKPTEEEIAERMEMTIEKLRFIAKSAQLPISLET IQEGSLGLERGVEKFDPTKGYKFSTYAYWWIRQAITRAIAQQGRTIRLPIHITEKLNKIKKTQRQLAQDLGRAATIAEIAEALELEPAQIREYFRVSRHPISLDV IQEGSLGLERGVEKFDPT'KGYKFSTYAYWWIRQAITRAIAQQGRTIRLPIHITEKINKIKKTQRELSQQLGRSATPAEVAKALEIDPSQIREYLSLSRQPISLDV IQEGALGLERGVEKFDPTLGYKFSTYAYWWIRQGITRAIAQQSRTIRLPIHMADKLNKIKCVQRELSQKLGYIAGVTEIAQALNLEPSQIREYLQLVRQPVSLDM IQEGTLGLERGVEKFDPSKGYKFSTYAYWWIRQAITRAIAQQSRTIRLPIHITEKL_NKLKKTQRELSQQLGRSATASELAEVLELPLEQVREYIQMNRQPVSLDV IQEGAIGLNRAAEKFDPNKGYKF STYAYWWIRQAITRTIANDARTIRLPIHIVEKLNKLKKAQRTLKQTLQRNPTEAELAQELDITADQLHQLLQLRRQSLSLNH IQEGAIGLNRAAEKFDPDKGYKFSTYAYWWIRQAITRTIANDART IRLPIHVVEKLNKIKKAQRSLKQELKRNPNEGELAAALDITPAQLRQLIQLRRQSLSLNH

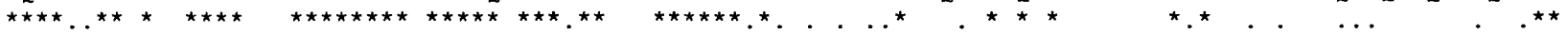

\author{
------ region 4.2
}

PIGKEEDSRLGDFIEAD-GETPEDQVSKSLLREDLENVLDTLSA-RERDVLRLRYGLDDGRMKTLEEIGQIFNVTRERIRQIEAKALRKLRHPNRNSILKEYIR 375 RVGDNQDTELMDLLEDS-GESPDNNVTYELLKQDLRDLIADLTP-QQQEVIILRFGLNDGKELSLAKIGKRMNLSRERVRQLERQALNHLRR--RRSQIREYLVAS 328 RVGDNQDTELSELLEDE-GVSPDAYITQESMRQDLQNLI_AELTP-QQQAVLTMRFGLNDGQELSLAKIGQHINNISRERVRQLENQALAQLKR--RRANMAEYIIAS 345 RIGFEQDTQLQLLKDD--GMSPERYAERELLYQDIHNLLAKLTP-QQKEVLILRFGLAGGCELTLVQISQRMGISRERVRQVEKQALTLLRR--YGIDSRSYLAD 331 KVGDSQDTELQELLEDE-QSSPSDYVEQESLRRDLRNLMAELTP-QQQAVIALRYGLDEGDSLSLAKVGERLNISRERVRKLERQAMDHLRR--RSRLLAEYAAS 320 RVGKGEDTELVDLLEDDGLQLPEERMSEAMMRQELWDVLGDVLTDREKEVIALRYGLSSEQPHTLEEVGGMFNLSRERVRQIQSKAMRKLRRPQVARRLKSWLY 365 RVGKGEDTELVDLLEDQQLQLPEDLMNESML_RREIVEVLAEVLTEREMEVICLRYGIASHQSYTLEEVGNMFNLSRERVRQIQSKAMRKLRRPQVARRLKGWL 369

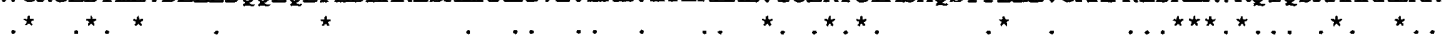

Fig. 2. Alignment of the predicted amino acid sequences of RNA polymerase sigma factors SigA, SigB and SigC from Synechococcus sp. PCC 7002 strain PR600 (Caslake \& Bryant, 1996; this work); RpoD2 from Synechococcus sp. PCC 7942 (Tsinoremas et al., 1996); Anabaena sp. PCC 7120 SigB (Brahamsha \& Haselkorn, 1992); and Synechocystis sp. PCC 6803 RpoD [GenBank accession numbers D63999 and (Kaneko et al., 1996a) D90908]. The overlined regions correspond to conserved regions $1,2,3$ and 4 of sigma factors as defined by Lonetto et al. (1992). Amino acid identities between proteins are indicated with an asterisk; conserved amino acids are indicated by a period; gaps introduced to align the protein sequences optimally are indicated by dashes. The alternative methionines in SigC that could serve as translation initiation starts, corresponding to codons 30 and 61 of sigC, are indicated by boldface type. The length of the respective proteins is indicated by the number of amino acids at the end of each respective sequence.

are $47 \%$ for SigA and SigB, $50 \%$ for SigB and SigC, and $63 \%$ for SigA and SigC. The three sigma factors from Synechococcus sp. PCC 7002 are also compared to selected sigma factors from other cyanobacteria in Fig. 2 , including Synechocystis sp. PCC 6803 (Kaneko et al., 1996a, b), Synechococcus sp. PCC 7942 (Tsinoremas et al., 1996) and Anabaena sp. PCC 7120 (Brahamsha \& Haselkorn, 1992). SigB described by Brahamsha \& Haselkorn (1992) and RpoD2 of Synechococcus sp. PCC 7942 are apparently homologous to SigB described here (Fig. 2); however, SigC of Anabaena sp. PCC 7120 is not a homologue of SigC described here but rather is most similar to SigE of Synechococcus sp. PCC 7002 (Gruber \& Bryant, 1997).

\section{Transcript analyses of sigB and sigC}

Total RNA was isolated from Synechococcus sp. strain PR6000 cells grown in replete medium and from cells deprived of nitrogen (Fig. 3) or carbon (Fig. 4) for increasing periods of time. The RNA samples were separated by electrophoresis, transferred to a nylon membrane and hybridized with the 917 bp HinclI-Bsm I fragment of the sigB gene (Fig. 3a, 4a) or the $792 \mathrm{bp}$ 


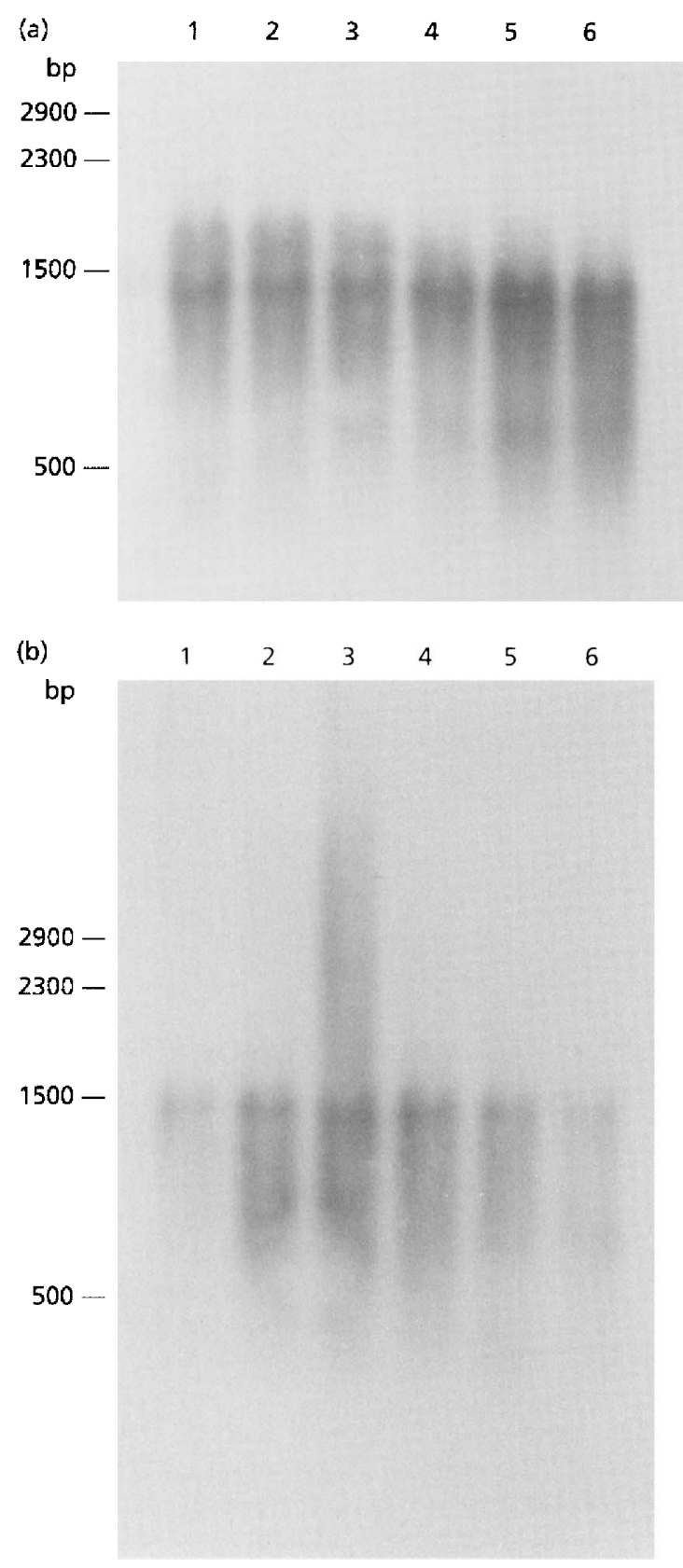

Fig. 3. Northern blot hybridization analyses of the Synechococcus sp. strain PR6000 sigB (a) and sigC (b) transcripts from cells undergoing nitrogen starvation. (a) The Northern blot was probed with a radiolabelled $917 \mathrm{bp} H$ Hincll-Bsml fragment of the sig $B$ gene (see Fig. 1a). (b) The Northern blot was probed with a radiolabelled $792 \mathrm{bp} X \mathrm{mnl}$-Aval fragment of the sigC gene (see Fig. 1b). Lanes 1, RNA extracted from cells grown under standard conditions. Lames $2-6$, RNAs from cells deprived of nitrogen for increasing periods of time: lanes 2,1 $\mathrm{h}$; lanes 3, $2 \mathrm{~h}$; lanes 4, $4 \mathrm{~h}$; lanes 5, $6 \mathrm{~h}$; lanes 6, $8 \mathrm{~h}$. Transcript sizes were estimated by comparison with 235 (Kumano et al., 1983) and 165 (Tomioka \& Sugiura, 1983) rRNAs and their breakdown products (Doolittle, 1972).

$X m n \mathrm{I}-A v a \mathrm{I}$ fragment of the sigC gene (Fig. 3b, 4b). The major $\operatorname{sig} B$ transcript class was approximately 1400 bases in length, and the relative abundance of the $\operatorname{sig} B$

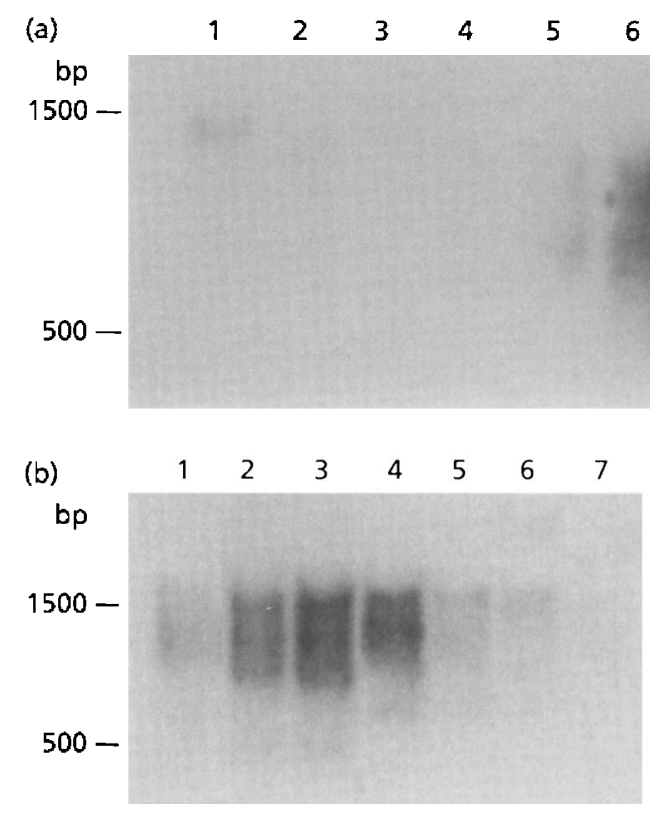

Fig. 4. Northern blot hybridization analyses of the Synechococcus sp. strain PR6000 sigB (a) and sigC (b) transcripts from cells undergoing carbon starvation. (a) The Northern blot was probed with a radiolabelled $917 \mathrm{bp} \mathrm{Hincll-Bsml} \mathrm{fragment}$ of the sigB gene (see Fig. 1a). (b) The Northern blot was probed with a radiolabelled 792 bp Xmnl-Aval fragment of the sigC gene (see Fig. 1b). Lanes 1, RNA extracted from cells grown under standard conditions. Lanes 2-7, RNAs from cells deprived of $\mathrm{CO}_{2}$ for increasing periods of time: lanes $2,1 \mathrm{~h}$; lanes $3,2 \mathrm{~h}$; lanes $4,4 \mathrm{~h}$; lanes 5, $6 \mathrm{~h}$; lanes $6,8 \mathrm{~h}$, lanes 7, $16 \mathrm{~h}$. Transcript sizes were estimated as described in the legend to Fig. 3.

transcripts increased after $4-8 \mathrm{~h}$ of nitrogen starvation. Transcripts larger than the most abundant species were also detected in RNA samples from cells grown in replete medium or from cells that had not been nitrogenstarved for long periods of time (Fig. 3a, lanes 1-3). The $s i g B$ transcript levels initially decreased in response to carbon starvation, but increased dramatically after $16 \mathrm{~h}$ of starvation (Fig. 4a). Furthermore, sigB transcript sizes decreased from approximately 1400 bases to about 1000 bases for the 16 h starvation time point (Fig. 4a), which was more apparent in a lighter exposure of the fluorogram (data not shown). No change in $\operatorname{sig} B$ transcript levels was detected in RNA isolated from cells grown under low light intensity or from cells subjected to a mild heat shock treatment $\left(45^{\circ} \mathrm{C}\right.$ for $60 \mathrm{~min}$; data not shown). The major sigC transcripts were approximately 1500 bases long, and sigC transcripts were less abundant than $\operatorname{sig} B$ transcripts in cells grown in replete medium. The sigC transcripts increased significantly during the first $2 \mathrm{~h}$ of nitrogen starvation and then decreased back to levels similar to those found in cells grown in replete medium. Likewise, during carbon starvation, sigC transcript levels increased to a maximum at approximately $2 \mathrm{~h}$ of starvation, and subsequently decreased until no transcripts were detected after $16 \mathrm{~h}$ of starvation (Fig. 4b). No obvious change in the size distribution of the $\operatorname{sig} C$ transcripts occurred during this time-course. 
(a)

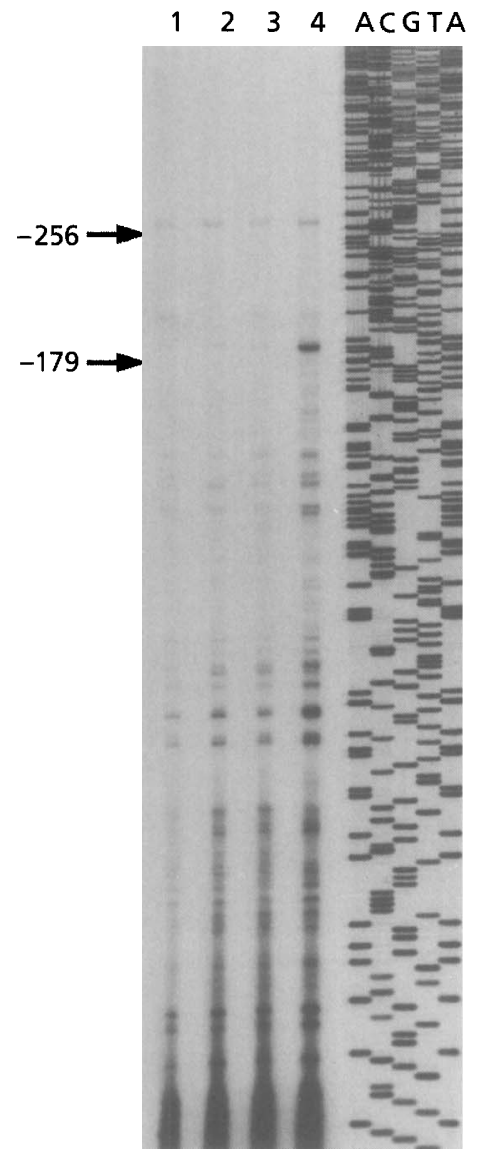

(b)

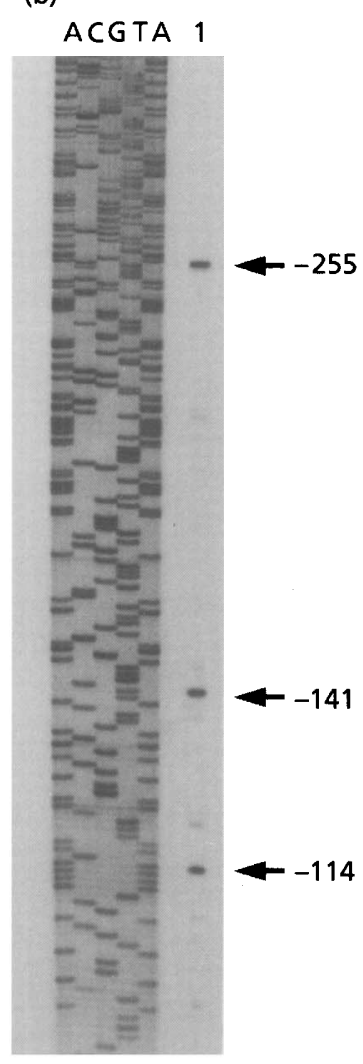

Fig. 5. Primer extension analyses of the Synechococcus $s p$. strain PR6000 sigB (a) and sigC (b) transcript. Lanes 1, RNA extracted from cells grown under standard conditions. (a) Lanes 2-4, RNA from cells deprived of nitrogen for increasing periods of time: lane 2, $2 \mathrm{~h}$; lane 3, $4 \mathrm{~h}$; lane 4, $8 \mathrm{~h}$. Primer extension products vvere denatured and subjected to electrophoresis alongside a DNA sequencing ladder generated using a universal primer on single-stranded M13 phage DNA (US Biochemicals). The two mapped $5^{\prime}$ endpoints are 256 and $179 \mathrm{nt}$ upstream of the translation start site for the sigB gene. (b) Primer extension products from the sigC gene were denatured and subjected to electrophoresis alongside a DNA sequencing ladder generated using the same primer on the EcoRV-Styl fragment. The mapped $5^{\prime}$ endpoints are 255, 141 and $114 \mathrm{nt}$ upstream of the translation start site for the longest SigC polypeptide.

Transcripts hybridizing to $\operatorname{sig} C$ probes appeared reproducibly as a smear, suggesting that this mRNA is relatively unstable; control hybridization experiments showed that this was not due to artifactual degradation of the RNA (data not shown).

Primer extension analyses to map the $5^{\prime}$ endpoints of the $\operatorname{sig} B$ transcripts were performed with RNA extracted from Synechococcus sp. strain PR6000 cells grown under standard growth conditions and with RNA extracted from cells deprived of nitrogen for $2 \mathrm{~h}, 4 \mathrm{~h}$, and $8 \mathrm{~h}$ (Fig. 5a). The longest primer extension product detected, corresponding to a $5^{\prime}$ endpoint 256 bases upstream of

the translation start site (denoted -256 in Fig. 5a), was not significantly affected by nitrogen starvation. However, transcripts with $5^{\prime}$ endpoints 179 bases upstream of the translation start site (denoted -179 in Fig. 5a) increased as the length of the starvation period increased. Additional potential endpoints were detected, but all of these increased equally in intensity as the duration nitrogen starvation increased. The predicted size of transcripts beginning 256 bases upstream of the translation start site and ending at the last $T$ of the inverted repeat is 1400 bases, a value that agrees well with the estimated size of the transcripts observed by Northern blot hybridization (Figs 3a, 4a).

To map the $5^{\prime}$ endpoints of the $\operatorname{sig} C$ transcripts, primer extension analysis was performed with RNA extracted from Synechococcus sp. strain PR6000 cells grown in replete medium under standard conditions (Fig. 4b). Three major $5^{\prime}$ endpoints were detected, at 255, 141 and 114 nucleotides upstream of the translation start site for the longest SigC polypeptide. The predicted size of transcripts beginning 255 bases upstream of the translation start site for the longest SigC polypeptide and ending at the last nucleotide of the inverted repeat is 1450 bases. This value is in excellent agreement with the size estimated for these transcripts from the Northern blot hybridization experiments (see Figs $3 b, 4 b$ ).

\section{Interposon mutagenesis of the sigB and sig $C$ genes}

To determine whether the $\operatorname{sig} B$ and $\operatorname{sig} C$ gene products are required for viability of Synechococcus sp. PCC 7002 and to learn more about the roles of these sigma factors in cellular physiology, each gene was insertionally inactivated by interposon mutagenesis. The aphII gene of Tn5, encoding aminoglycoside 3 -phosphotransferase II and conferring resistance to kanamycin, was inserted into a unique restriction site within the coding sequence of each gene (see Fig. 1a, b). After repeated streaking to allow segregation of alleles to occur, Southern-blot hybridization analyses of chromosomal DNA isolated from selected transformants confirmed that complete segregation had occurred and that both the $\operatorname{sig} B$ and sigC genes were insertionally inactivated as anticipated (data not shown). Thus, neither $\operatorname{sig} B$ nor $\operatorname{sig} C$ is essential for viability of Synechococcus sp. PCC 7002, and SigB and SigC can be classified as group 2 sigma factors (Lonetto et al., 1992). The Synechococcus sp. PCC 7002 strain in which the $\operatorname{sig} B$ gene has been insertionally inactivated has been designated PR6501. The Synechococcus sp. PCC 7002 strain in which the sigC gene has been insertionally mutagenized has been designated PR6502. The growth rates of the two mutant strains were identical to that of the wild-type strain under nutrient-replete, standard growth conditions. The growth rates of the mutants were also similar to that of the wild-type under steady-state conditions of reduced $\mathrm{CO}_{2}$ (air-levels), iron, sulfate or nitrate concentrations, and low light intensity (approximately $60 \mu \mathrm{E} \mathrm{m}^{-2} \mathrm{~s}^{-1}$ ). However, the $\operatorname{sigC}$ mutant grew noticeably more slowly after a $\mathrm{CO}_{2}$ shift-down from $1 \%$ to $0.03 \%$, suggesting 
(a)

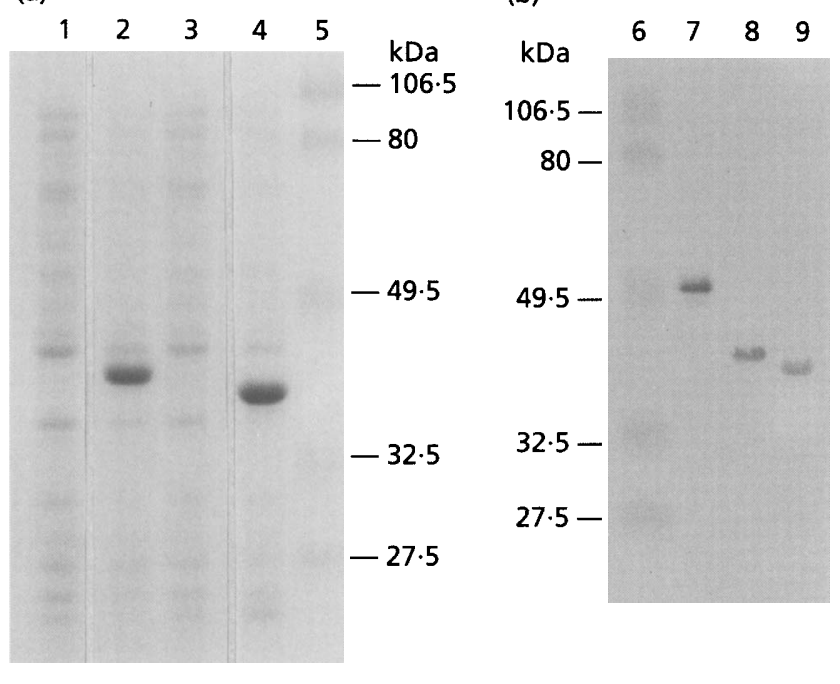

Fig. 6. SDS-PAGE (a) and immunoblot (b) analyses of the overproduction of Synechococcus sp. strain PR6000 SigB and SigC polypeptides. (a) Coomassie-blue-stained SDS-PAGE $10 \%$ acrylamide gel. Lanes 1-4, whole-cell extracts of: lane 1, E. coli $B L 21(D E 3)$ containing the pET11aSigB plasmid; lane 2, E. coli BL21(DE3) containing the pET11aSigB plasmid after $4 \mathrm{~h}$ induction with IPTG; lane 3, E. coli BL21(DE3)pLysS containing the pET3dSigC plasmid; lane 4, E. coli BL21(DE3)pLysS containing the $\mathrm{pET} 3 \mathrm{dSigC}$ plasmid after $4 \mathrm{~h}$ induction with IPTG. Lane 5, low-molecular-mass prestained standards. (b) Immunoblot analysis of whole-cell extracts from (a) using the Synechococcus sp. strain PR6000 SigA antibody. Lane 6, lowmolecular-mass prestained protein standards; lane 7, E. coli BL21(DE3) containing the pET11aSigA plasmid after $4 \mathrm{~h}$ induction with IPTG; lane 8, E. coli BL21(DE3) containing the pET11aSigB plasmid after $4 \mathrm{~h}$ induction with IPTG; lane 9, E. coli BL21(DE3)pLysS containing the pET3dSigC plasmid after $4 \mathrm{~h}$ induction with IPTG.

that $\mathrm{SigC}$ might play a role in the ability to adapt to changes in this critical nutrient. A full description of these effects will be described elsewhere (T. Gruber \& D. A. Bryant, unpublished).

\section{Overproduction and analyses of recombinant SigB and SigC}

SigB and SigC were overproduced in E. coli using using a T7 RNA polymerase based expression system (Studier et al., 1990) as described in Methods. As shown in Fig. $6(\mathrm{a})$, large amounts of both SigB $(41 \mathrm{kDa}$; Fig. 6a, lane 2) and SigC $(39 \mathrm{kDa}$; Fig. $6 \mathrm{a}$, lane 4$)$ could be produced after induction of the T7 RNA polymerase; the overproduced proteins were largely recovered as inclusion bodies (data not shown). Recombinant SigB and SigC were electrophoretically transferred to PVDF membrane filters and subjected to both amino- and carboxyterminal sequence analysis. The carboxy-terminal sequences determined for SigB and SigC exactly matched the predicted amino acid sequence. Recombinant SigB had proline at its amino-terminus, and thus the aminoterminal methionine had been post-translationally removed (see Fig. 2). Since the actual start codon for the
sigC gene was not known, and since at the time these experiments were performed no other closely related sequences were available in the databases, the overproduction clone for SigC was arbitrarily constructed using the second potential methionine initiation codon (see Figs 1 and 2). The amino-terminal sequence of recombinant SigC had a mixture of methionine and valine at the amino terminus (see Fig. 2). The sequence (M)ALQE ... was not detected during sequencing, and thus the third potential methionine initiation codon is not recognized as a start codon in E. coli. These results indicate that, in spite of their relative mobilities upon SDS-PAGE (Fig. 6a), the actual molecular mass of recombinant SigB was $38 \mathrm{kDa}$ while that of recombinant SigC was $39 \mathrm{kDa}$. Anomalous electrophoretic mobilities have been noted for several other sigma factors and have been attributed to the large percentage of charged residues that occur in these proteins (Burton et al., 1981; Chang \& Doi, 1990; Brahamsha \& Haselkorn, 1991).

In previous work polyclonal rabbit antibodies to Synechococcus sp. PCC 7002 SigA were produced (Caslake \& Bryant, 1996). Fig. 6(b) shows an immunoblot prepared with proteins from whole-cell extracts of $E$. coli strains induced to overproduce SigA (Fig. 6b, lane 7), SigB (Fig. 6b, lane 8) and SigC (Fig. 6b, lane 9). Although antibodies to SigA cross-react with SigB and $\mathrm{SigC}$, this heterologous cross-reaction was much weaker than the homologous reaction with SigA.

\section{Immunoblot analyses of sigma factors in extracts of Synechococcus sp. PCC 7002 cells grown under different conditions}

Immunoblot analyses were employed to follow the relative levels of SigA, SigB and SigC in cells grown under nutrient-replete conditions and after nutrient starvation. Crude RNA polymerase fractions were prepared from Synechococcus sp. strains PR6501 and PR6502 grown under standard growth conditions in replete medium and from wild-type strain PR6000 grown in replete medium or subjected to nitrogen starvation for $12 \mathrm{~h}$ or carbon starvation for $16 \mathrm{~h}$. Fig. 7 (a) shows the Coomassie-blue-stained proteins separated during SDS-PAGE analysis of these crude RNA polymerase fractions. Although it is clearly not possible to detect directly polypeptides that can be identified as the sigma factor subunits, this figure demonstrates that approximately equal amounts of protein were loaded for each sample. Fig. 7(b) shows an immunoblot analysis of the RNA polymerase preparations shown in Fig. 7(a) using antibodies to Synechococcus sp. PCC 7002 SigA. The major cross-reacting protein in lanes 2-6 (apparent mass $49 \mathrm{kDa}$ ) is presumed to be the SigA polypeptide synthesized in vivo. Because an alternative start codon was used for production of the (larger) recombinant SigA protein (Fig. $7 \mathrm{~b}$, lane 7 ), the naturally occurring SigA protein comigrates with a minor component of the recombinant SigA protein (for complete details, see Caslake \& Bryant, 1996). For cells grown under standard growth conditions, the relative abundances of 
(a)

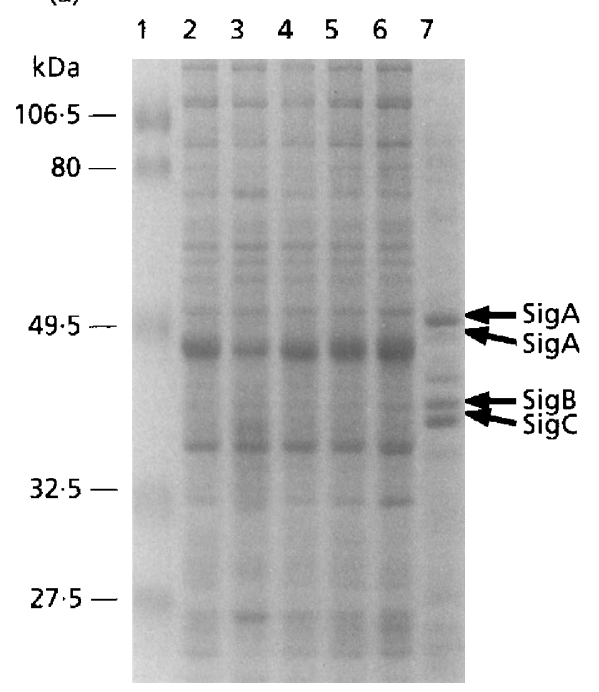

(b)

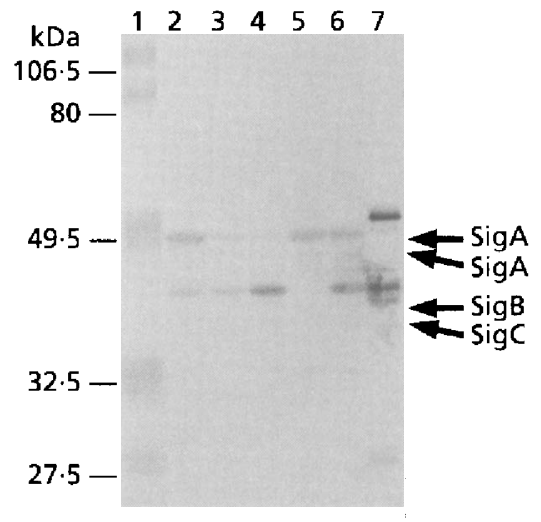

(c)

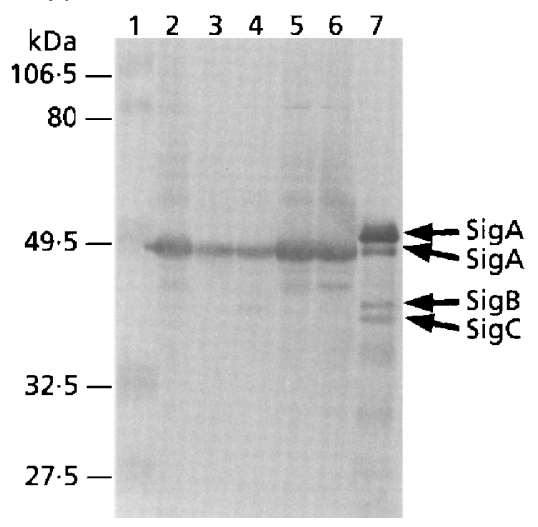

Fig. 7. SDS-PAGE (a) and immunoblot (b, c) analyses of partially purified RNA polymerase from Synechococcus sp. strain PR6000 and mutants. Lanes 1, low-molecular-mass prestained protein standards. Lanes 2-6, partially purified RNA polymerase from: lane 2, Synechococcus sp. strain PR6000 grown in replete medium; lane 3, Synechococcus sp. strain PR6000 grown in replete medium and then starved for nitrogen for $12 \mathrm{~h}$; lane 4, Synechococcus sp. strain PR6000 grown in replete medium and then starved for carbon for $16 \mathrm{~h}$; lane 5, Synechococcus sp. strain PR6501 grown in replete medium; lane 6, Synechococcus sp. strain PR6502 grown in replete medium. Lane 7, a mixture of whole-cell extracts from E. coli BL21(DE3) containing the pET11aSigA, pET11aSigB plasmids, and BL21(DE3)pLysS cells containing the pET3dSigC plasmid after $4 \mathrm{~h}$ induction with IPTG. (a) Coomassie-blue-stained SDS-PAGE $10 \%$ acrylamide gel. (b, c) Immunoblot analyses of partially purified RNA polymerase preparations from (a) probed with the Synechococcus sp. strain PR6000 SigA antibodies (b) or with the B. subtilis $\sigma^{43}$ antibodies (c). Recombinant SigA, SigB, and SigC are indicated on the right side of each panel.

SigA in the crude RNA polymerase fraction of sig $B$ mutant strain PR6501 (Fig. 7b, lane 5) and sigC mutant strain PR6502 (Fig. 7b, lane 6) were similar to the level observed in the wild-type strain pPR6000 (Fig. 7b, lane 2). However, the relative abundance of SigA in extracts of the wild-type strain after starvation for nitrogen (Fig. $7 b$, lane 3) or carbon (Fig. 7b, lane 4) was significantly lower than the level found in the control cells grown in replete medium (Fig. $7 \mathrm{~b}$, lane 2 ). Antibodies to the Synechococcus sp. PCC 7002 SigA protein cross-reacted very weakly with a polypeptide with the apparent mass of recombinant SigB, but no cross-reacting species with a mass similar to that of the recombinant SigC protein could be detected in any extract.

Fig. 7(c) shows an immunoblot analysis of the same cell extracts shown in panels (a) and (b) but using antibodies raised against the RpoD (or $\sigma^{43}$ ) protein of $B$. subtilis (Chang \& Doi, 1990). As can be seen from the intensity of the cross-reactions to the control recombinant protein mixture in lane 7, these antibodies recognized the three sigma factor proteins of Synechococcus sp. PCC 7002 more or less equivalently. As also shown in Fig. $7(b)$ with antibodies to SigA, SigA levels decreased during nitrogen (Fig. 7c, lane 3) and carbon starvation (Fig. 7c, lane 4) and appeared to be of the same abundance in RNA polymerase preparations isolated from cells grown under standard growth conditions from the wild-type strain PR6000 (Fig. 7c, lane 2), the sigB mutant strain
PR6501 (Fig. 7c, lane 5) and sigC mutant strain PR6502 (Fig. 7c, lane 6). The antibodies to the $\sigma^{43}$ protein of $B$. subtilis also recognized a protein in the crude polymerase fractions with an apparent mass of $41 \mathrm{kDa}$; this protein co-migrated with the overproduced SigB protein (Fig. $7 \mathrm{c}$, lane 7 ), but no polypeptide corresponding to SigC was detected with this antibody. Strongly supporting the identification of this cross-reacting protein as SigB, this polypeptide was not detected in extracts from the $\operatorname{sig} B$ mutant strain PR6501 (Fig. 7c, lane 5). The relative abundances of the SigA and SigB polypeptides changed significantly in response to nitrogen and carbon starvation (compare Fig. 7c, lane 2 to lanes 3 and 4). Low levels of the SigB polypeptide were detected in strain PR6000 grown under nutrient-replete conditions (Fig. $7 \mathrm{c}$, lane 2), and similar levels of the SigB polypeptide were detected after nitrogen starvation for $12 \mathrm{~h}$ (Fig. 7c, lane 3). Thus, the ratio of SigB to SigA increased significantly after nitrogen limitation. An even greater increase in the level of the SigB polypeptide was observed after carbon starvation for $16 \mathrm{~h}$ (Fig. $7 \mathrm{c}$, lane 4); since the SigA level also decreased under this growth condition, the SigB:SigA ratio was even larger under these conditions. Since our RNA polymerase enrichment procedure involves heparin-agarose chromatography, the immunoblot analyses suggest that the number of RNA polymerase holoenzymes containing the SigA polypeptide decreases during nitrogen and carbon starvation, while those associated with the SigB polypeptide 
increase during the same treatments. Interestingly, SigB levels were as high in the sigC mutant strain PR6502 (Fig. 7c, lane 6) as in the carbon-starved cells of the wildtype strain (Fig. 7c, lane 4); however, SigA levels under nutrient-replete conditions were not detectably affected by the absence of SigC in strain PR6502. These observations strongly suggest that the ratio of SigB to SigA is important in determining the cellular response to changes in carbon and nitrogen availability in the environment.

\section{DISCUSSION}

In this work the $\operatorname{sig} B$ and $\operatorname{sig} C$ genes, encoding two alternative sigma factors, were cloned and characterized from Synechococcus sp. PCC 7002. Since strains harbouring null mutations in $\operatorname{sig} B$ and $\operatorname{sig} C$ were viable under standard laboratory growth conditions, the products of these genes can be categorized as group 2 sigma factors (Lonetto et al., 1992; Gruber \& Bryant, 1997). Multiple group 2 sigma factors have now been identified in several cyanobacteria, including Synechococcus sp. PCC 7002 (Caslake \& Bryant, 1996; Gruber \& Bryant, 1997), Synechococcus sp. PCC 7942 (Tanaka et al., 1992a, b; Tsinoremas et al., 1996), Anabaena sp. PCC 7120 (Brahamsha \& Haselkorn, 1991, 1992), and Synechocystis sp. PCC 6803 (Kaneko et al., 1996a, b). Analysis of the complete genome of Synechocystis sp. PCC 6803 (Kaneko et al., 1996a, b) has revealed that this cyanobacterium can produce up to eight sigma factors: one group 1 sigma factor; four group 2 sigma factors; one group 3 sigma factor with strong sequence similarity to SigB of B. subtilis (Binnie et al., 1986) and homologues in Staphylococcus aureus (Wu et al., 1996) and Streptomyces sp. (Kato et al., 1995); and two members of the group 3-RpoE subfamily (Lonetto et al., 1994). Homologues of each of these eight sigma factors have been identified in the genome of Synechococcus sp. PCC 7002 (Caslake \& Bryant, 1996; Gruber \& Bryant, 1997; T. Gruber \& D. A. Bryant, unpublished results).

Functional studies of RNA polymerase and group 1 sigma factors from Anabaena sp. PCC 7120 (Schneider et al., 1991) and Calothrix sp. PCC 7601 (Schyns et al., 1994) strongly suggest that the cyanobacterial promoters recognized by these principal sigma factors will have strong sequence similarity to the -10 and -35 promoter motifs of E. coli, B. subtilis, and other eubacteria (Harley \& Reynolds, 1987; Moran, 1993; Haldenwang, 1995; Record et al., 1996). Conserved region 2.4 is involved in recognition of the -10 motif of promoters (Helmann \& Chamberlin, 1988; Lonetto et al., 1992; Malhotra et al., 1996). Since region 2.4 of all group 1 and 2 sigma factors, including the SigB and SigC proteins described here, is virtually invariant in amino acid sequence (Gruber \& Bryant, 1997), it can be surmised that most eubacterial promoters recognized by group $1+2$ sigma factors will contain -10 motifs similar to the $E$. coli consensus. Conserved region 4.2 recognizes the -35 motif of promoters (Helmann \& Chamberlin, 1988; Lonetto et al., 1992). Since some residues of region
4.2 that are known to be involved in -35 motif recognition are also invariant, it can be assumed that significant sequence conservation in the -35 recognition motif will also occur. However, there is greater sequence variation in region 4.2 of group $1+2$ sigma factors, and it is probable that some variation in the preferred -35 motifs of promoter regions may occur. Nitrocellulose filter binding assays have shown that the E. coli $\sigma^{70}$ is highly sensitive to the interhexamer spacing (Dombroski et al., 1996). The strong collinearity of all group $1+2$ sigma factor sequences between regions 2.1 and 4.2 strongly implies that the preferred spacing for the -10 and -35 motifs will be close to $17 \mathrm{nt}$ for all promoters (Gruber \& Bryant, 1997).

The high degree of sequence similarity among all group 1 and group 2 sigma factors in the regions expected to interact with the -10 and -35 promoter motifs raises the question of how these sigma factors might differ functionally from the primary sigma factors. One possibility is that these alternative sigma factors could exhibit significantly different responses to activators or repressors. A number of subunits of the RNA polymerase, including $\alpha, \beta^{\prime}$ and $\sigma$, have been shown to interact with activators and repressors (reviewed by Ptashne \& Gann, 1997). Region 4 of RpoD in E. coli has been shown to interact specifically with activators (Busby $\&$ Ebright, 1994). The bacteriophage $\lambda$ cI protein binds to a site centred at position -42 and overlaps the -35 element of the $\lambda \mathrm{P}_{\mathrm{RM}}$ promoter (Li et al., 1994). An allele-specific intergenic suppressor of the cl mutation (Li et al., 1994) was isolated in the RpoD protein (R596H); this suppressor substitution occurs just after the helix-turn-helix motif that binds the -35 motif of the promoter. $\mathrm{Hu} \&$ Gross (1985) also found that residue $\mathrm{R} 596$ of $\mathrm{RpoD}$ affects activation of transcription by AraC and MalT. The corresponding regions from the carboxy-terminal portion of region 4.2 to the carboxyterminus of the SigA, SigB and SigC proteins differ significantly and hence might interact in very different ways with activators or repressors. A second domain, highly variable both in length and sequence, extends from the amino-terminus to region 2.1 of the group $1+2$ sigma factors. For SigA, SigB and SigC of Synechococcus sp. PCC 7002, this domain is 146,99 and 133 amino acids, respectively, and there is very little sequence similarity among the three proteins in this region (Fig. 2). As with other sigma factors which have been studied (Dombroski et al., 1992, 1993), the amino-terminal amino acids may inhibit or modulate the DNA-binding activity of each sigma factor. These highly variable regions could also be responsible for specific functions of the various group $1+2$ sigma factors and could confer significant differences in the ability to be modulated by transcription activators or repressors, without necessarily requiring differences in promoter recognition properties.

The effects of various environmental conditions on the expression of the $\operatorname{sig} B$ and sigC genes were examined in Synechococcus sp. PCC 7002. Northern blot hybridization and primer extension analyses indicated that the 
relative abundance of $\operatorname{sig} B$ transcripts increased significantly when cells were starved for nitrogen or carbon. This observation is similar to that reported for nitrogenstarved cells of Anabaena sp. PCC 7120 (Brahamsha \& Haselkorn, 1992). A change in the predominant $5^{\prime}$ endpoint of the transcripts occurred as well, suggesting that a new promoter was used for transcription of this gene under these conditions. In this study SigB protein levels seem to correlate rather well with the transcript levels. For example, the levels of both mRNA and protein are elevated in cells that have been starved for carbon for $16 \mathrm{~h}$, although the protein levels did not increase to the same degree as transcript levels. Protein turnover, or other post-transcriptional events, may also be involved in regulating the levels of SigB protein in cells. Nonetheless, the ratio of SigA to SigB changed significantly, since the levels of SigA associated with RNA polymerase were much lower after nitrogen starvation. It was previously shown that $\operatorname{sig} A$ transcripts decrease in abundance when cells are starved for nitrogen for increasing periods of time (Caslake \& Bryant, 1996), and it has also been found that carbon limitation causes a decrease in $\operatorname{sig} A$ transcript levels (data not shown). Interestingly, the highest levels of SigB protein were detected in cells that had been starved for carbon (Fig. $7 \mathrm{~b}, \mathrm{c}$ ). These results strongly suggest that SigB levels are altered in response to changes in carbon and nitrogen metabolism in these cells. A change in the SigA: SigB ratio could, in combination with interactions with additional activators or repressors, significantly alter the rate of transcription of specific operons during nutrient stress conditions. The increased levels of SigB in the sigC mutant could indicate that both the regulation and functions of these two sigma factors overlap such that loss of one protein can be compensated for by increased expression of the other. Alternatively, the loss of SigC may cause an increase in transcription of the $\operatorname{sig} B$ gene. Studies are now being conducted to distinguish among these possibilities.

Transcripts for the sigC gene initially increased and then decreased during nitrogen and carbon starvation, and sigC levels were much higher in cells grown at $1 \% \mathrm{CO}_{2}$ than in cells grown on air. In cells grown under nutrientreplete conditions, transcripts for the sigC gene were less abundant than those of either the sigA (Caslake \& Bryant, 1996) or $\operatorname{sig} B$ genes (see Fig. 3). Using antibodies to SigA of Synechococcus sp. PCC 7002 and RpoD of B. subtilis, we were unable to detect the SigC protein in either whole-cell extracts or RNA-polymerase-enriched fractions, although both antibodies weakly cross-reacted with recombinant SigC produced in E. coli. To overproduce the SigC protein in E. coli, the second potential methionine start codon was arbitrarily selected and re-engineered as the start codon for the expression construct used in E. coli. At the time these studies were completed, no other cyanobacterial sequences with strong similarity to SigC were available. However, since the entire Synechocystis sp. PCC 6803 genome has subsequently been sequenced (Kaneko et al., 1996a, b) and encodes a homologue of SigC, this decision can now be re-evaluated. The length and limited sequence similarity between the amino-terminal regions of the two SigC proteins suggest that the first potential methionine start codon may actually be used in Synechococcus sp. PCC 7002. If the first methionine were to be used as the start codon, the predicted protein product would have a mass of $42 \cdot 2 \mathrm{kDa}$ and would be $3 \cdot 2 \mathrm{kDa}$ larger than the product that was overproduced in these studies in E. coli (see Fig. 6). Since the SigB protein migrates anomalously slowly upon SDS-PAGE, a larger SigC protein might have co-migrated with SigB in the RNA-polymeraseenriched fractions from Synechococcus sp. PCC 7002. Nevertheless, SigC should have been detectable in the $\operatorname{sig} B$ mutant strain PR6501, but only SigA was detected in extracts of this strain. Resolution of this issue will require antibodies with much higher specificity for the SigC protein.

The observed changes in the SigA : SigB ratio provoked a variety of experiments to search for phenotypic differences between the wild-type strain and the $\operatorname{sig} B$ and sigC mutant strains in response to nitrogen starvation, nitrogen readdition and growth properties on different nitrogen sources and $\mathrm{CO}_{2}$ levels. Under conditions of nitrogen or carbon starvation, Synechococcus sp. can degrade up to $90 \%$ of the phycobiliproteins for maintenance metabolism (Tandeau de Marsac \& Houmard, 1993; Grossman et al., 1994). After readdition of nitrogen or carbon, the phycobiliproteins are resynthesized. It has been shown that genes for the major phycobiliproteins phycocyanin and allophycocyanin are not transcribed during nitrogen or carbon starvation (Gasparich et al., 1987; Wealand et al., 1989; Zhou et al., 1992). To test whether SigB was involved in the degradation or resynthesis of phycobiliproteins, nitrogen was removed from cultures of Synechococcus sp. strains PR6000 and PR6501 in the mid-exponential growth phase. At increasing times after nitrogen removal, up to $24 \mathrm{~h}$, nitrogen was readded and phycobiliprotein contents of the cells were determined. No difference between Synechococcus sp. strains PR6000 and PR6501 was detectable (data not shown). This may mean that $\operatorname{SigB}$ is not involved in this response to nitrogen starvation, or may mean that SigB is part of a redundant system and can be replaced by another sigma factor. Recent experiments involving carbon limitation have been more revealing. Growth of the sigC mutant strain was noticeably slower immediately after a stepdown from $1 \% \mathrm{CO}_{2}$ to $0.03 \% \mathrm{CO}_{2}$, although steadystate growth on air-levels of $\mathrm{CO}_{2}$ was identical for the wild-type and the $\operatorname{sig} C$ mutant strain (data not shown). Given the central importance of carbon metabolism in autotrophs, it is possible that redundant regulatory responses also exist to allow cells to respond to changes in the availability of inorganic carbon. Additional physiological studies of the $\operatorname{sig} B$ and $\operatorname{sig} C$ mutant strains will be published elsewhere.

In conclusion, the results presented here suggest that the alternative sigma factors SigB and SigC of Synechococcus sp. PCC 7002 play a role in adaptive responses to a cellular imbalance in carbon and nitrogen metab- 
olism. In this regard, it is interesting to note that the Synechocystis sp. PCC 6803 genome does not contain any genes with significant homology to the rpoN gene, encoding the $\sigma^{54}$ sigma factor that plays important roles in nitrogen-regulated gene expression in enteric bacteria (Kustu et al., 1989). With the clues to function identified in these studies, future studies will focus on changes in expression patterns of genes whose expression is known to be strongly modulated by the cellular balance of carbon and nitrogen metabolism in cyanobacteria (Tandeau de Marsac \& Houmard, 1993; Bryant, 1994).

\section{ACKNOWLEDGEMENTS}

This work was supported by USPHS grant GM31625 awarded to D. A.B. The authors thank Dr Jindong Zhao for performing amino- and carboxy-terminal amino acid sequence analyses, Dr Roy Doi for antibodies to the $\sigma^{43}$ protein of Bacillus subtilis, and Drs Stephen Wagner and B. Tracy Nixon for their pHC79 cosmid library of Synechococcus sp. strain PR6000.

\section{REFERENCES}

Binnie, C., Lampe, M. \& Losick, R. (1986). Gene encoding the sigma 37 species of RNA polymerase sigma factor from Bacillus subtilis. Proc Natl Acad Sci USA 83, 5943-5947.

Brahamsha, B. \& Haselkorn, R. (1991). Isolation and characterization of the gene encoding the principal sigma factor of the vegetative cell RNA polymerase from the cyanobacterium Anabaena sp. strain PCC 7120. J Bacteriol 173, 2442-2450.

Brahamsha, B. \& Haselkorn, R. (1992). Identification of multiple RNA polymerase sigma factor homologs in the cyanobacterium Anabaena sp. strain PCC 7120: cloning, expression and inactivation of the $\operatorname{sig} B$ and sigC genes. J Bacteriol 174, 7273-7282.

Bryant, D. A. (editor) (1994). The Molecular Biology of Cyanobacteria. Dordrecht: Kluwer.

Bukau, B. (1993). Regulation of the Escherichia coli heat-shock response. Mol Microbiol 9, 671-680.

Bult, C. J., White, O., Olsen, G. J. \& 37 other authors (1996). Complete genome sequence of the methanogenic archaeon, Methanococcus jannaschii. Science 273, 1058-1073.

Burgess, R. R., Travers, A. A., Dunn, J. J. \& Bautz, E. K. F. (1969). Factor stimulating transcription by RNA polymerase. Nature 221, 43-46.

Burton, Z. F., Burgess, R. R., Lin, J., Moore, D., Holder, S. \& Gross, C. A. (1981). The nucleotide sequence of the cloned $r p o D$ gene for the RNA polymerase sigma subunit from E. coli K12. Nucleic Acids Res 9, 2889-2903.

Busby, S. \& Ebright, R. H. (1994). Promoter structure, promoter recognition, and transcription activation in prokaryotes. Cell 79, 743-746.

Buzby, J. S., Porter, R. D. \& Stevens, S. E., Jr (1983). Plasmid transformation in Agmenellum quadruplicatum PR-6: construction of biphasic plasmids and characterization of their transformation properties. J Bacteriol 154, 1446-1450.

Caslake, L. F. \& Bryant, D. A. (1996). The sigA gene encoding the major $\sigma$ factor of RNA polymerase from the marine cyanobacterium Synechococcus sp. strain PCC 7002: cloning and characterization. Microbiology 142, 347-357.

Chang, B. Y. \& Doi, R. H. (1990). Overproduction, purification and characterization of the Bacillus subtilis polymerase $\sigma^{\mathbf{A}}$ factor. $J$ Bacteriol 172, 3257-3263.
Curtis, S. E. \& Martin, J. A. (1994). The transcription apparatus and the regulation of transcription initiation. In The Molecular Biology of Cyanobacteria, pp. 613-639. Edited by D. A. Bryant. Dordrecht: Kluwer.

Dombroski, A. J., Walter, W. A., Record, M. T., Jr, Siegele, D. A. \& Gross, C. A. (1992). Polypeptides containing highly conserved regions of transcription initiation factor $\sigma^{70}$ exhibit specificity of binding to promoter DNA. Cell 70, 501-512.

Dombroski, A. J., Walter, W. A. \& Gross, C. A. (1993). Aminoterminal amino acids modulate $\sigma$-factor DNA-binding activity. Genes Dev 7, 2446-2455.

Dombroski, A. J., Johnson, B. D., Lonetto, M. \& Gross, C. A. (1996). The sigma subunit of Escherichia coli RNA-polymerase senses promoter spacing. Proc Natl Acad Sci USA 93, 8858--8862.

Doolittle, W. R. (1972). Ribosomal ribonucleic acid synthesis and maturation in the blue-green alga Anacystis nidulans. J Bacteriol 111, 316-324.

Gasparich, G. E., Buzby, J., Bryant, D. A., Porter, R. D. \& Stevens, S.E., Jr (1987). The effects of light-intensity and nitrogen starvation on the phycocyanin promoter in the cyanobacterium Synechococcus PCC 7002. In Progress in Photosynthesis Research, vol IV, pp. 761-764. Edited by J. Biggins. Dordrecht: MartinusNijhoff.

Goodrich, J. A. \& Tjian, R. (1994). TBP-TAF complexes: selectivity factors for eukaryotic transcription. Curr Opin Cell Biol 6, 403-409.

Grossman, A. D., Erickson, J. W. \& Gross, C. A. (1984). The $b t p R$ gene product of $E$. coli is a sigma factor for heat-shock promoters. Cell 38, 383-390.

Grossman, A. R., Schaefer, M. R., Chiang, G. G. \& Collier, J. L. (1994). The responses of cyanobacteria to environmental conditions: light and nutrients. In The Molecular Biology of Cyanobacteria, pp. 641-675. Edited by D. A. Bryant. Dordrecht: Kluwer.

Gruber, T. \& Bryant, D. A. (1997). Molecular systematic studies of eubacteria using $\sigma^{70}$-type sigma factors of Group 1 and Group 2. J Bacteriol 179, 1734-1747.

Haldenwang, W. G. (1995). The sigma factors of Bacillus subtilis. Microbiol Rev 59, 1-30.

Harley, C. B. \& Reynolds, R. P. (1987). Analysis of E. coli promoter sequences. Nucleic Acids Res 15, 2343-2361.

Helmann, J. D. \& Chamberlin, M. J. (1988). Structure and function of bacterial sigma factors. Annu Rev Biochem 57, 839-872.

Hu, J. \& Gross, C. (1985). Mutations in the sigma subunit of Escherichia coli RNA polymerase which affect positive control of transcription. Mol Gen Genet 199, 7-13.

Kaneko, T., Sato, S., Kotani, H. \& 21 other authors (1996a). Sequence analysis of the genome of the unicellular cyanobacterium Synechocystis sp. strain PCC6803. II. Sequence determination of the entire genome and assignment of potential protein-coding regions. DNA Res 3, 109-136.

Kaneko, T., Sato, S., Kotani, H. \& 21 other authors (1996b). Sequence analysis of the genome of the unicellular cyanobacterium Synechocystis sp. strain PCC6803. II. Sequence determination of the entire genome and assignment of potential protein-coding regions (supplement). DNA Res 3, 185-209.

Kato, F., Hino, T., Nakaji, A., Tanaka, M. \& Koyama, Y. (1995). Carotenoid synthesis in Streptomyces setonii ISP5395 is induced by the gene $c r t S$, whose product is similar to a sigma factor. $\mathrm{Mol}$ Gen Genet 247, 387-390.

Kolter, R., Siegele, D. A. \& Tormo, A. (1993). The stationary phase of the bacterial life cycle. Annu Rev Microbiol 47, 855-874. 
Kumano, M., Tomioka, N. \& Sugiura, M. (1983). The complete nucleotide sequence of a $23 \mathrm{~S}$ rRNA gene from a blue-green alga, Anacystis nidulans. Gene 24, 219-225.

Kustu, S., Santero, E., Keener, J., Popham, D. \& Weiss, D. (1989). Expression of $\sigma^{54}(n t r A)$-dependent genes is probably united by a common mechanism. Microbiol Rev 53, 367-376.

Laemmli, U. K. (1970). Cleavage of structural proteins during the assembly of the head of bacteriophage T4. Nature 227, 680-685.

Li, M., Moyle, H. \& Susskind, M. M. (1994). Target of the transcriptional activation function of phage $\lambda \mathrm{cl}$ protein. Science $263,75-77$.

Liu, X. \& Matsumura, P. (1995). An alternative sigma factor controls transcription of flagellar class-III operons in Escherichia coli: gene sequence, overproduction, purification and characterization. Gene $164,81-84$.

Lonetto, M. A., Gribskov, M. \& Gross, C. A. (1992). The $\sigma^{70}$ family: sequence conservation and evolutionary relationships.J Bacteriol 174, 3843-3849.

Lonetto, M. A., Brown, K. I., Rudd, K. E. \& Buttner, M. J. (1994). Analysis of the Streptomyces coelicolor sigE gene reveals the existence of a subfamily of eubacterial RNA polymerase $\sigma$ factors involved in the regulation of extracytoplasmic functions. Proc Natl Acad Sci USA 91, 7573-7577.

McCann, M. P., Kidwell, J. P. \& Matin, A. (1991). The putative $\sigma$ factor KatF has a central role in development of starvationmediated general resistance in Escherichia coli. J Bacteriol 173, 4188-4194.

Mager, W. M. \& de Kruijff, A. J. J. (1995). Stress induced transcriptional activation. Microbiol Rev 59, 506-531.

Malhotra, A., Severinova, E. \& Darst, S. (1996). Crystal structure of a $\sigma^{70}$ subunit fragment from E. coli RNA polymerase. Cell 87 , $127-136$.

Moran, C. P., Jr (1993). RNA polymerase and transcription factors. In Bacillus subtilis and Other Gram-positive Bacteria: Biochemistry, Physiology, and Molecular Genetics, pp. 653-667. Edited by A. L. Sonenshein, J. A. Hoch \& R. Losick. Washington, DC: American Society for Microbiology.

Mulvey, M. R. \& Loewen, P. C. (1989). Nucleotide sequence of $k a t F$ of Escherichia coli suggests KatF protein is a novel sigma transcription factor. Nucleic Acids Res 17, 9979-9991.

Nohno, T., Kasai, Y. \& Saito, T. (1988). Cloning and sequencing of the Escherichia coli chlEN operon involved in molybdopterin biosynthesis. J Bacteriol 170, 4097-4102.

Ptashne, M. \& Gann, A. (1997). Transcriptional activation by recruitment. Nature 386, 569-577.

Record, M. T., Jr, Reznikoff, W. S., Craig, M. L., McQuade, K. L. \& Schlax, P. J. (1996). Escherichia coli RNA polymerase $\left(\mathrm{E} \sigma^{70}\right)$, promoters, and the kinetics of the steps of transcription initiation. In Escherichia coli and Salmonella: Cellular and Molecular Biology, vol. 1, pp. 792-820. Edited by F. C. Neidhardt. Washington, DC: American Society for Microbiology.

Richardson, J. P. \& Greenblatt, J. (1996). Control of RNA chain elongation and termination. In Escherichia coli and Salmonella: Cellular and Molecular Biology, vol. 1, pp. 822-848. Edited by F.
C. Neidhardt. Washington, DC: American Society for Microbiology.

Schneider, G. J., Lang, J. D. \& Haselkorn, R. (1991). Promoter recognition by the RNA polymerase from vegetative cells of the cyanobacterium Anabaena 7120. Gene 105, 51-60.

Schyns, G., Sobczyk, A., Tandeau de Marsac, N. \& Houmard, J. (1994). Specific initiation of transcription at a cyanobacterial promoter with RNA polymerase purified from Calothrix sp. PCC 7601. Mol Microbiol 13,887-896.

Siegele, D. A., Hu, J. C., Walter, W. A. \& Gross, C. A. (1989) Altered promoter recognition by mutant forms of the $\sigma^{70}$ subunit of Escherichia coli RNA polymerase. J Mol Biol 206, 591-603.

Stragier, P. (1991). Dances with sigmas. EMBO 10, 3559-3566.

Studier, F. W., Rosenberg, A. H., Dunn, J. J. \& Dubendorff, J. W. (1990). Use of T7 RNA polymerase to direct expression of cloned genes. Methods Enzymol 185, 60-89.

Tanaka, K., Shiina, T. \& Takahashi, H. (1991). Nucleotide sequence of genes $h r d A, h r d C$, and $h r d D$ from Streptomyces coelicolor A3(2) having similarity to $r p o D$ genes. Mol Gen Genet 229, 334-340.

Tanaka, K., Shiina, T. \& Takahashi, H. (1992a). Multiple $r p o D$ related genes of cyanobacteria. Biosci Biotechnol Biochem 56, 1113-1117.

Tanaka, K., Shiina, T. \& Takahashi, H. (1992b). The complete nucleotide sequence of the gene $r p o D 1$ encoding the prinicipal $\sigma$ factor of the RNA polymerase from the cyanobacterium Synechococcus sp. strain PCC 7942. Biochim Biophys Acta 1132, 94-96.

Tandeau de Marsac, N. \& Houmard, J. (1993). Adaptation of cyanobacteria to environmental stimuli: new steps towards molecular mechanisms. FEMS Microbiol Rev 104, 119-190.

Tomioka, N. \& Sugiura, M. (1983). The complete nucleotide sequence of a $16 \mathrm{~S}$ ribosomal RNA gene from a blue-green alga, Anacystis nidulans. Mol Gen Genet 191, 46-50.

Tsinoremas, N. F., Ishiura, M., Kondo, T., Andersson, C. R., Tanaka, K., Takahashi, H., Johnson, C. H. \& Golden, S. S. (1996). A sigma factor that modifies the circadian expression of a subset of genes in cyanobacteria. EMBO J 15, 2488-2495.

Wealand, J. L., Myers, J. A. \& Hirschberg, R. (1989). Changes in gene expression during nitrogen starvation in Anabaena variabilis ATCC 29413. J Bacteriol 171, 1309-1313.

Wu, S., de Lencastre, H. \& Tomasz, A. (1996). Sigma-B, a putative operon encoding alternate sigma factor of Stapbylococcus aureus RNA polymerase: molecular cloning and DNA sequencing. $J$ Bacteriol 178, 6036-6042.

Yanisch-Perron, C., Vieira, J, \& Messing, J. (1985). Improved M13 phage cloning vectors and host strains: nucleotide sequences of the M13mp18 and pUC19 vectors. Gene 33, 103-119.

Zhou, J., Gasparich, G. E., Stirewalt, V. L., de Lorimier, R. \& Bryant, D. A. (1992). The $c p c E$ and $c p c F$ genes of Synechococcus sp. PCC 7002: construction and phenotypic characterization of interposon mutants. J Biol Chem 267, 16138-16145.

Received 25 April 1997; revised 6 August 1997; accepted 11 August 1997 